\title{
Living cockroach genus Anaplecta discovered in Chiapas amber (Blattaria: Ectobiidae: Anaplecta vega sp.n.)
}

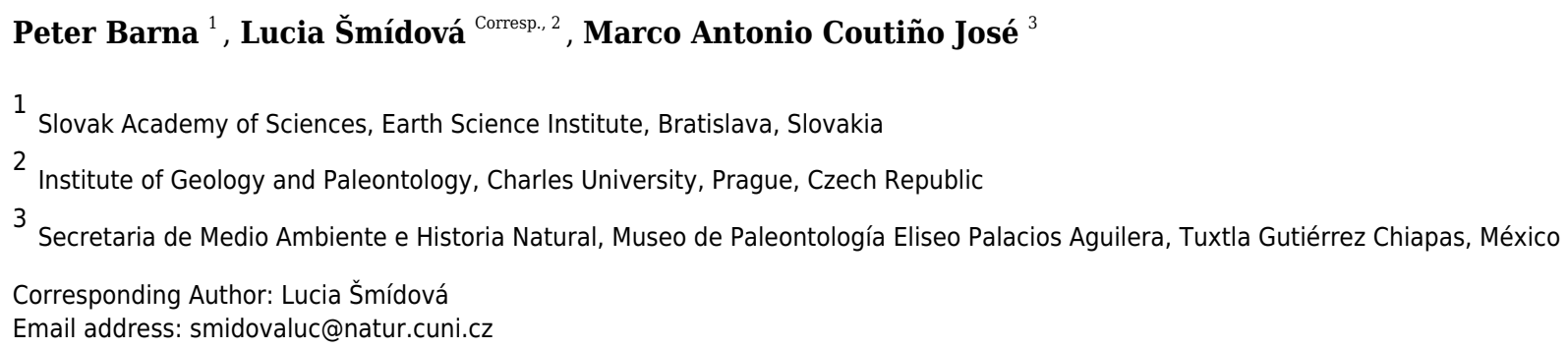

Cenozoic cockroaches are recent and with two indigenous exceptions, based on their fragmentary preservation state, they cannot be discriminated formally from representatives of living genera. Anaplecta vega sp.n. - the second described cockroach from Miocene (23 Ma) Simojovel amber (Mexico: Chiapas: Los Pocitos) is characterized by a slender, under $5 \mathrm{~mm}$ long body, prolonged mouthparts bearing long maxillary palps with a distinct flattened triangular terminal palpomere, large eyes and long slender legs with distinctly long tibial spines. Some leg and palpal segments differ in dimensions on the left and right sides of the body, indicating (sum of length of left maxillary palpomeres $65 \%$ longer than right; right cercus 13\% longer than left cercus) dextro-sinistral asymmetry. The asymmetrically monstrous left palp is unique and has no equivalent. In concordance with most Cenozoic species, the present cockroach does not show any significantly primitive characters such as a transverse pronotum characteristic for stem Ectobiidae. The genus is cosmopolitan and 10 species live also in Mexico, including Chiapas, today. Except for indigenous taxa and those characteristic for America, this is the first Cenozoic American cockroach taxon representing a living cosmopolitan genus, in contrast with representaties of Supella Shelford, 1911 from the same amber source that are now extinct in the Americas. 


\section{Living cockroach genus Anaplecta discovered in Chiapas amber}

2 (Blattaria: Ectobiidae: Anaplecta vega sp.n.)

3

4 PETER BARNA ${ }^{1}$, LUCIA ŠMÍDOV $\mathbf{A}^{2 *}$ and MARCO ANTONIO COUTIÑO
5 JOSÉ

6

71 Earth Science Institute, Slovak Academy of Sciences, Dúbravská cesta 9, P.O. BOX 105, 84005

8 Bratislava 45, Slovakia; peter.barna@savba.sk

92 Charles University, Institute of Geology and Palaeontology, Albertov 6, 128 43, Prague, Czech

Republic; smidovaluc@natur.cuni.cz

3 Secretaria de Medio Ambiente e Historia Natural, Museo de Paleontología Eliseo Palacios Aguilera,TuxtlaGutiérrez Chiapas, México; coutinojma@hotmail.com

* corresponding author

\section{ABSTRACT}

Cenozoic cockroaches are recent and with two indigenous exceptions, based on their fragmentary preservation state, they cannot be discriminated formally from representatives of living genera. Anaplecta vega sp.n. - the second described cockroach from Miocene (23 Ma) Simojovel amber (Mexico: Chiapas: Los Pocitos) is characterized by a slender, under $5 \mathrm{~mm}$ long body, prolonged mouthparts bearing long maxillary palps with a distinct flattened triangular terminal palpomere, large eyes and long slender legs with 
distinctly long tibial spines. Some leg and palpal segments differ in dimensions on the left and right sides of the body, indicating (sum of length of left maxillary palpomeres $65 \%$ longer than right; right cercus $13 \%$ longer than left cercus) dextro-sinistral asymmetry. The asymmetrically monstrous left palp is unique and has no equivalent. In concordance with most Cenozoic species, the present cockroach does not show any significantly primitive characters such as a transverse pronotum characteristic for stem Ectobiidae. The genus is cosmopolitan and 10 species live also in Mexico, including Chiapas, today. Except for indigenous taxa and those characteristic for America, this is the first Cenozoic American cockroach taxon representing a living cosmopolitan genus, in contrast with representaties of Supella Shelford, 1911 from the same amber source that are now extinct in the Americas.

\section{Introduction.}

The stem Dictyoptera, containing all cockroaches, originated in the Late Carboniferous (Zhang et al. 2012, Calisto \& Piñeiro, 2019) and adapted during their evolution to various environments, leading to diverse morphological adaptations including diversification of the Order Mantodea (mantises) during the Late Jurassic/Early Cretaceous (Legendre et al., 2015; Vršanský \& Aristov 2014).

Anaplecta is a cockroach genus currently placed within Ectobiidae, a family that evolved during the Mesozoic (Vršanský, 1997). Species in the subfamily Anaplectinae are small, beetlelike and mostly active during the night (Rentz, 2014). Both sexes are fully winged and can be found in the leaf litter of rainforests (Foottit \& Adler, 2017). 

ambers written by Grimaldi \& Ross (2004), Vršanský (2004, 2008ab, 2009, 2010), Anisyutkin \&

Gorochov (2008), Poinar (2009), Vršanský et al. (2011, 2013ab, 2014, 2018abc, 2019), Vršanský

\& Bechly (2015), Bai et al. (2016, 2018), Poinar \& Brown (2017), Sendi \& Azar (2017),

Šmídová \& Lei (2017), Vršanský \& Wang (2017), Kočárek (2018ab), Li \& Huang, (2018),

Mlynský et al., 2019 and Podstrelená \& Sendi (2018), Sidorchuk \& Khaustov (2018), Qui et al.

(2019 ab). In total, we know 11 families recorded in Mesozoic ambers out of which 3 are still

living. There are 59 Cenozoic cockroaches (including the newly described $A$. vega) as listed in

51 Table 1.

(TABLE 1 NEAR HERE)

The Miocene Mexican amber originated from resinous exudates of Hymenaea sp., a leguminose tree developed near the ancient coast, in estuarine environments, very similar to mangroves

55 (Poinar 1992) and is well studied with precise dating at 23Ma (Vega et al. 2009) and with more than 110 currently cataloged insect species (EDNA fossil insect database active 20/11/2018 and

57 Vršanský et al. 2011). Cockroaches are represented by the genus Ischnoptera Burmeister, 1838 reported by Solórzano-Kraemer (2007, although the identification needs further support) and

59 Supella miocenica (Vršanský et al. 2011).

60 The extant genus Anaplecta is today a widely distributed circumtropic taxon (see Beccaloni

61 2014) and its ecology remains very little known. Fossils of the genus Anaplecta, aside from

62 Mexican amber are also known from Eocene Baltic amber and Chinese ambers (P. Barna; 1.11. -

63 20.11.2013, Moscow, PIN RAS and private collection V. Gusakov, specimen number PIN

64 964/1322; personal observation) and undescribed Anaplecta are also reported from Dominican 
65 amber (Gutiérrez \& Pérez-Gelabert 2000), but it is unclear whether the mentioned specimens do

66 not represent the common Plectoptera electrina Gorokhov et Anisyutkin in Gorokhov (2007) -

67 locations are marked in Fig. 1E.

68

69

70

71

72

73

74

75

76

77

(FIGURE 1 NEAR HERE)

\section{Material and methods.}

The studied holotype of Anaplecta vega, sp.n. (catalogue number IHNFG-5323) comes from Miocene (23Ma) Simojovel amber (Mexico: Chiapas), Los Pocitos (9243'46"W, 1708'53"N). The specimen is stored in Paleontological Collection of the Museo de Paleontología "Eliseo Palacios Aguilera", ascribed to Secretaría de Medio Ambiente e Historia Natural (SEMAHN) of the Chiapas Government, Mexico under the catalogue number IHNFG-5323.

The specimens Anaplecta xanthopeltis Hebard, 1921 (MNHN-EP-EP1398) and Anaplecta maronensis Hebard, 1921 (MNHN-EP-EP1385), used for comparison with living Anaplecta, are deposited at the National Museum of Natural History in Paris, France.

Photographs were taken with a KEYENCE digital microscope, which took pictures from different locations and focal depth and then automatically combined them into a single stacked photo. This type of picture was also used as a basis for making a highly detailed line drawing in CorelDrawX3, where we used additional photographs of separate parts of the cockroach body. These were taken with a LEICA MZ6 binocular loupe and LEICA EC3 camera. The dorsal drawing was manually made using a drawing ink pen applied over a transparent paper.

Abbreviations used: $1=$ length; $\mathrm{w}=$ width (all in $\mathrm{mm}$ ). 
86 The electronic version of this article in Portable Document Format (PDF) will represent a

87 published work according to the International Commission on Zoological Nomenclature (ICZN),

88 and hence the new names contained in the electronic version are effectively published under that

89 Code from the electronic edition alone. This published work and the nomenclatural acts it

90 contains have been registered in ZooBank, the online registration system for the ICZN. The

91 ZooBank LSIDs (Life Science Identifiers) can be resolved and the associated information viewed

92 through any standard web browser by appending the LSID to the prefix http://zoobank.org/. The

93 LSID for this publication is: [article: urn:lsid:zoobank.org:pub:FD6F76DB-BF88-4FBA-8737-

94 F00B408C54E1]. The online version of this work is archived and available from the following

95 digital repositories: PeerJ, PubMed Central and CLOCKSS.

96

97 SYSTEMATIC PALAEONTOLOGY

98 Order Blattaria Latreille, 1810 (= Blattodea Brunner von Wattenwyl, 1882)

99 Family Ectobiidae Brunner von Wattenwyl, 1865

100 Subfamily Anaplectinae Walker, 1868

101 Genus Anaplecta Burmeister, 1838

102 Type species: Anaplecta lateralis Burmeister, 1838

103 Composition. An up-to date list can be found in the online database 'Cockroach Species File

104 Online', which was founded by George Beccaloni (2014) based on the world catalogue of

105 cockroaches compiled by Karlis Princis (1962, 1963, 1964, 1965, 1966, 1967, 1969). 
106 Occurrence. Circumtropical; during Eocene also in Baltic, Dominican and China areas (in 107 preparation by authors), which had a subtropical climate that time. Stratigraphic range: Eocene108 living.

112 Types. One complete adult specimen (Holotype kept in Paleontological Museum in Tuxtla, 113 Mexico) with folded wings, probably male, enclosed in a small piece of amber. Catalogue 114 number IHNFG-5323.

115 Type horizon and locality. Lower Miocene, Mazantic Shale. Los Pocitos locality NW from 116 Simojovel de Allende in Chiapas, Mexico. 92 $43^{\prime} 46^{\prime \prime} \mathrm{W}, 17^{\circ} 08^{\prime} 53^{\prime \prime} \mathrm{N}$.

117 Material. Type only.

118 Etymology. After VEGA (Vedecká Grantová Agentúra - Research grant agency of the Slovak 119 Republic) and also after Dr. Francisco Vega (UNAM, Mexico city) who did so much for 120 progressing research on Chiapas amber.

121 Differential diagnosis. Small slender roach with body $l=4.89$ (excluding antennae and cerci) 122 and $\mathrm{w}=2.00$; subtriangular rounded pronotum; prolonged head with unique large eyes and huge 123 asymmetrical maxillary palps; antennae similar in length as the body; tegmina reaching apex of 124 abdomen; long slender legs bearing long tibial spines. 
125 Differs from all species, except for A. xanthopeltis, in having a derived simplified form of the 126 pronotum (without paranotalia and transverse shape) and, except for $A$. maronensis, a derived 127 reticulated forewing venation.

Differs from recent species from Mexico (since this genus contains a large number of species worldwide and no other fossil species of this genus were described from this area): $A$. azteca Saussure, 1868 is larger, its pronotum is double the length and width of the pronotum of A. vega, the pronotum length is $1 / 3$ of tegmina length, while in $A$. vega it is $1 / 4$. pronotum is distinctly larger, can reach almost two times the dimension of the pronotum of $A$. vega; the pronotum length can be more than $1 / 3$ or even $1 / 2$ of the tegmina length. Anterior margin ascending under sharper angle from the distal third of tegmen length forming a rounded angle, while in $A$. vega it is at the beginning of the most distal fifth of the tegmen length.

A. mexicana Saussure, 1868; while having a similar tegmina length and pronotum length ratio, the whole body is significantly larger and the tegmina length is double the tegmina length of $A$. vega. The shape of tegmina differs with the anterior margin slightly sinusoid without any pronounced angulation, the tegmina apex is more broadly rounded and positioned around the middle of the tegmen width. A. nahua Saussure, 1868 is larger, the tegmina length: pronotum

142 length ratio is quite similar to that of $A$. vega. tegmina in apical third strongly narrowed unlike $A$. vega. Its anterior margin does not look angular in the apical fifth and is curved smoothly, and the radius area of the tegmina is much narrower. 
147 A. saussurei Hebard, 1921 has a similar size and similar shaped tegmina as $A$. vega, but the

148 tegmina reach slightly beyond the cercal apices, are slightly wider, their anterior margin in the

149 basal part is almost straight, the clavus is distinctly longer and wider, the pronotum is larger and

150 the pronotum length is $1 / 3$ of the tegmina length.

151 A. tolteca Saussure, 1868 is larger but the tegmina length: pronotum length ratio is the same as in 152 A. vega.

153 A comparison of dimensions of $A$. vega $\mathrm{n}$. sp. and the above mentioned Mexican species is

154 presented in Tab. 2A; a comparison of $A$. vega n. sp. dimensions and an average of the 155 mentioned Mexican species dimensions is shown in Tab 2C.

156 (FIGURE 2 NEAR HERE)

157

158 Description.

159 Detailed measurements are in the Table 2.

160 Body small and slender $(1=4.89, \mathrm{w}=2.00)$, tegmina reaching apex of abdomen, legs long and 161 slender carrying large tibial spines, antennae similar in length to the body.

162 Pronotum subtriangular, rounded, cranially arched over head $(1=1.00, \mathrm{w}=1.27)$, long erect setae 163 sparsely distributed along pronotum margin and on its dorsal surface. Pronotum length is $1 / 4$ of 164 tegmina length.

165 Scutellum triangular, cranio-caudally prolonged (length of scutellum part not covered by 166 pronotum $=0.29, \mathrm{w}=0.14)$. 
167 Tegmina total $1=4.04,1$ of part not covered by pronotum $=3.89$, left tegmen $\mathrm{w}=1.28$; visible left

168 clavus $1=1.16, \mathrm{w}=0.67$. Basal half of tegmina inflated with exception of anterior peripheral

169 areas (costal area, part of radial area). Anterior margin in the apical fifth of tegmen length starts

170 to tilt posteriad more strongly, which gives it an angular look. Apex postero-apically sharpened.

171 Costal area wide. Radial field in apical half wide, branches of radius almost all simple (one

172 secondary dichotomy observed in right tegmen, left tegmen veins weakly visible). Surface

173 sclerotized, but not fully elytrized, without prominent structures. Sparsely distributed medium

174 sized setae occur at anterior and apical margins of tegmina and medium sized to long setae on

175 tegminal veins. Only a very small portion of right tegmen is covered by left tegmen. Clavus $1=$

1761.16 (only the visible uncovered part), $\mathrm{w}=1.23$.

177 Hind wings covered by tegmina, folded in half as standard for the genus.

178 Head with prolonged mouthparts and large eyes, which in lateral view cover almost the entire

179 head excluding mouthparts; head $\mathrm{w}=0.76$, length from top of vertex to distal part of mandibles $=$

1800.91 , distance from occipital foramen to top of frons $=0.47$; eyes subovoid in lateral view, eye

181 length $($ parallel to head length $)=0.42$, eye width $($ perpendicular to eye 1$)=0.34$, interocular $\mathrm{w}=$

$1820.4 \mathrm{~mm}$. Three medium-sized setae positioned between left eye ommatidia near gena . Vertex

183 sparsely covered by setae ranging from short to very long; frons and clypeus with few distinctly

184 long setae, gena posteriorly with three distinct medium sized setae and smaller thin setae along

185 eye margin. Maxillary palps long with broad triangular terminal segment; dimensions of

186 palpomeres of right and left maxillary palp differ (right 1 st palpomere $\mathrm{l}=0.13, \mathrm{w}=0,06$; left $1 \mathrm{st}$

187 palpomere $\mathrm{l}=0.13, \mathrm{w}=0,09 ;$ right 2 nd palpomere $\mathrm{l}=0.1, \mathrm{w}=0.05 ;$ left 2 nd palpomere $\mathrm{l}=0.14$,

$188 \mathrm{w}=0.07$; right 3rd palpomere $\mathrm{l}=0.31, \mathrm{w}=0.06$; left 3 rd palpomere $\mathrm{l}=0.4, \mathrm{w}=0.09$; right 4 th

189 palpomere $\mathrm{l}=0.17, \mathrm{w}=0.07$; left 4 th palpomere $\mathrm{l}=0.29, \mathrm{w}=0.14$; right 5 th palpomere $\mathrm{l}=0.27, \mathrm{w}$ 
190

191

192

193

194

195

196

197

198

199

200

201

202

203

204

205

206

207

208

209

210

unmeasurable due to position of the cockroach body in the amber; left 5 th palpomere $1=0.34, \mathrm{w}=$ 0.21 , apical contacting surface 0.34 ; plot of left and right palpomeres length comparison is shown in Tab. 2B. Labial palps considerably smaller than maxillary palps, terminal palpomere triangular, distally widened. Only 2nd and 3rd left labial palpomere sufficiently visible to be measured: 2 nd left palpomere $1=0.11$, 3rd left labial palpomere $1=1.13$.

Antennae length similar to body length. First three antennomeres only with few setae, more distal antennomeres are richly covered by distinct setae, which exceed and in some parts double the width of antennomeres.

Scape large (left $\mathrm{l}=0.33$; right $\mathrm{l}=0.29)$ with wide proximal half $(\mathrm{left} \mathrm{w}=0.13)$ and sharp transition into narrower distal half $(\mathrm{w}=0.09)$, distal ending oblique with five setae.

Pedicel cylindrical (left $\mathrm{l}=0.21$, left $\mathrm{w}=0.08$; right $\mathrm{l}=0.2$ ), distal end oblique with distinct sharp angle at one side and wider than proximal end. Proximal third swollen on one side. Setae very few in number.

Segments of flagellum, 32 in left antenna, 28 in right antenna. Each segment is more or less wider in its distal part than in its proximal part. Setae longer than the width of flagellar segments.

First flagellar segment (third antenomere) slightly elongated, length is almost two times as its largest width (left $\mathrm{l}=0.14, \mathrm{w}=0.07)$. Following basal flagellomeres are short almost square shaped flagellomeres only slightly longer than wide. The subsequent row of flagellomeres has a lengthening trend distad.

Tab. 2E shows a chart that compares left and right antennomeres lengths of individuals. 
211 Cerci 7-segmented. 1st cercomere and 7th cercomere thinner than the rest, while the 7th

212 distinctly tapers distally forming a sharp end, cercomeres 2-6 sublenticullar, being similar in

213 shape and size. Left cercus total $1=1.00$, right cercus total $1=1.13$; Setae on cercomeres have

214 different dimensions, from small ones ranging from $1 / 3$ or $1 / 4$ of the cercomere length to thicker

215 prominent setae approximately the size of the cercomere length (maximal $l=0.21$, but majority

216 around 0.14 ) and long thin setae the size of two or three cercomeres which occur at the rate of 1

217 or 2 per cercomere. The entire surface of the cerci is also covered by very small short

218 microsetae.

220 Legs slender and very long (hind legs longer than body) with large spines (longer than

221 tarsomeres, except the 1st tarsomere) on tibia and distal end of femur.

222 Fore coxae subtrigonal with convex anterior margin, widest before middle, more slender in

223 distal half. Few setae present along the posterior margin.

224 Fore trochanteri very thin, barely visible.

225 Fore femora slender (left fore femur $1=1.29, \mathrm{w}=0.2$, right fore femur $1=0.67$, maybe more,

226 visibility obscured by damage of amber) with subparallel ventral and dorsal margins, which are

227 only slightly convex, narrower in proximal part and in distal third of their length. Anteroventral

228 margin in distal half with $20 \pm$ shorter spines, posteroventral margin with 13 (observed) longer

229 setae sparsely distributed along fore femur length, two thicker spines present on anterior surface

230 of proximal half of fore femur. Terminally three long serrated spines present: anteroventral,

231 posteroventral, anterodorsal. Rest of forefemoral surface covered only by a low number of

232 shorter setae, mostly concentrated in dorsal part. 
233 Fore tibiae distinctly more slender than fore femora, generally retaining similar width $(\mathrm{w}=0.07)$

234 throughout its length (left fore tibia $1=0.89$, right fore tibia $1=0.73$ ), except for the thinner arched

235 proximalmost spineless part $(\mathrm{w}=0.06)$, and neglectable changes of width due to elevations

236 around large, articulated, serrated spines; these spines are up to 0.29 long and 0.01 wide with

237 three spines in the middle third of the tibial length and two peripheral spines facing dorsad, the

238 middle one facing posteriad. Four large spines are at the distal end of the tibia ( 1 anteroventral, 1

239 anterior, 1 dorsal, 1 posterior). Distribution of large spines is the same on both right and left fore

240 tibiae. Along dorsal and ventral side and distal half of anterior surface are sparsely distributed

241 medium-sized setae.

242 Fore tarsi being 5-segmented, very slender, covered by setae exceeding their width $(\mathrm{w}=0.04)$,

243 terminated by trilobal arolium and two thin arcuate, more or less symmetrical claws with

244 widened bases.

245 Middle coxae (distal part obscured by damage in amber and another leg) larger and wider than

246 fore coxae, on posterior margin few setae present; distal end has distinct smaller lobe with 6

247 longer setae.

248 Middle trochanteri wide (width is only a little less than length), slightly curved.

249 Middle femora elongated with slightly convex dorsal and ventral side (ventral side being almost

250 straight) with bigger width around the middle of length (left middle femur $\mathrm{l}=1.44, \mathrm{w}=0.22 \mathrm{~mm}$;

251 right middle femur $\mathrm{l}=0.91, \mathrm{w}=0.17$ ). Setae sparsely distributed around dorsal margin, ventral

252 margin with 6 larger thick setae and $1-2$ medium-sized setae between each two consequent

253 larger setae; on proximal half of middle femur present anteroventrally two longer, anterad facing 
254 spines; on distal end of middle femur present 3 large serrated spines, one anteroventrally, one

255 posteroventrally and one dorsally.

256 Middle tibiae similar in length (left tibia $1=1.16$, right tibia $=1.11$ ), but left tibia $1 / 6$ shorter than

257 left middle femur, right tibia 1/5 longer than right middle femur; width varying along tibial

258 length as result of elevations at the bases of spines (minimum $\mathrm{w}=0.07$, maximum $\mathrm{w}=0.1) ; 10$

259 large serrated spines (maximal $1=0.36, \mathrm{w}=0.01$ ) facing differently (on left middle tibia 1

260 anteroventral, 1 posteroventral, 4 anterodorsal 4 posterodorsal) along tibial length, 4 terminal

261 large serrated spines (anteroventral, posteroventral, posterodorsal, anterodorsal) and one shorter

262 spine (posteroventral).

263 Middle tarsi 5-segmented, slender, covered by medium sized setae exceeding tarsal width ( $\mathrm{w}=$

$2640.04 \mathrm{~mm}$ ), terminated by two arched slender claws with widened bases and trilobal arolium.

265 Hind coxae badly visible.

266 Hind trochanteri slender, slightly curved with few setae, left hind trochanter $\mathrm{l}=0.43, \mathrm{w}=0.11$;

267 right hind trochanter $\mathrm{l}=0.46, \mathrm{w}=0.09$.

268 Hind femora larger than fore and mid femur $(1=1.4$, w of right hind femur $=0.31$, left one in

269 wrong position to be measured) with biggest width in the middle of their length, distal end

270 slightly widened, ventral side only slightly convex, dorsal side more convex. Numerous short

271 setae scattered through whole surface of femur. Setae sized from short to long present along

272 dorsal femoral margin, getting longer distad; at anterior surface setae with dark bases present at

273 an arched line subparallel to the dorsal side of femur, which proximally starts around the middle

274 of hind femur width, approaching dorsal side of hind femur distad. Dorsal and anterior setae are

275 longer on left fore femur. Anteroventral edge with medium-sized setae and two large spines in 
276 the middle third of hind femur length. Posteroventral edge with five long setae (left hind femur)

277 and shorter setae between them. Terminally three long serrated spines present: anteroventral,

278 posteroventral, anterodorsal.

279 Hind tibiae longer than fore and mid tibiae (left hind tibia $\mathrm{l}=1.89$, right hind tibia $\mathrm{l}=2.13$ ) near

280 double length of middle tibiae, width of hind tibiae is weakly varying due to elevations at bases

281 of larger spines, but not showing a significant narrowing or widening trend (maximal $\mathrm{w}=0.13$ ),

282 exception is the proximal $1 / 6$ which is more slender $(\mathrm{w}=0.1 \mathrm{~mm})$. Each hind tibia has along its

283 length 17 long serrated spines ( 3 anteroventral, 2 posteroventral, 7 anterodorsal, 5 posterodorsal)

284 and 5 long serrated terminal spines ( 1 anteroventral, 2 posteroventral, 1 posterodorsal, 1

285 anterodorsal), which makes together 22 spines on one hind tibia (maximal spine $1=0.5 \mathrm{~mm}$

286 maximal $\mathrm{w}=0.02$ ). Medium sized seatae are sparsely distributed along ventral and dorsal margin

287 (up to 4 between two spines).

288 Hind tarsi larger than fore and mid tarsi, 5-segmented, slender, covered by medium sized setae

289 most of which equal in size or exceeding tarsal width $(\mathrm{w}=0.06)$, terminated by two arched

290 slender claws with widened bases and trilobal arolium (pulvilli absent or indistinct). 1st

291 tarsomere very longwith almost same width throughout its length, in proximal part slightly

292 thinner; covered by distinct medium sized setae, most prominent is the ventral row of setae, other

293 areas have less densely distributed thinner setae; subsequent tarsomeres have the same length on

294 left and right hind leg.

295 Comparison of length of each leg femora, tibiae and tarsomeres is visible in Tab. 2 D.

296 Occurrence. Lower Miocene, 23Ma. Chiapas amber, Mexico. 
298

299

300

301

302

303

304

305

306

307

308

309

310

311

312

313

314

315

316

317

318

(TABLE 2 NEAR HERE)

\section{DISCUSSION}

The assignment of the herein described specimen to the subfamily Anaplectinae is in accordance with Grandcolas (1996). The majority of autapomorphies listed there are observable also in $A$. vega. Long, straight setae on pronotum, strong sharp apophysis on the anterior arch and transverse folding of hind wings are present. However, the vannus with short successive dichotomies on its first vein was not observed. The studied specimen was assigned to the genus Anaplecta on the basis of the overall body shape, shape of the pronotum, smooth dorsal half of the body, large axe-like terminal mandibular palpomere (however, it does not have the same length as the former palpomere, as mentioned in the original description of the genus), coriaceous tegmina, hind wings folded in half, arrangement of femoral setae and spines, large cerci, and tarsomeres without pulvilli. The specimen is most similar to and compared with the holotypes of South American A. xanthopeltis Hebard, 1921 and A. maronensis Hebard, 1921, which have the same type of pronotum, overall tegmina shape, tegmina type of venation and hind wings folding. Anaplectinae is usually considered a problematic group with an interesting systematic background. It is manifested both in morphological and molecular analysis as a "long branch", the most basal, earliest derived group among extant standard cockroaches according to the molecular analyses (Klass \& Meier, 2006; Legendre et al., 2015). In contrast, the fossil record reveals earlier branched Ectobiidae and Blattidae (Sendi \& Azar, 2017) and Anaplecta is considered more recent. 
319 It is an interesting fact, that the evolution of this group is accelerated, which is not only reflected

320 in sclerotisation of the fore wing, but also in simplification of venation, which probably

321 happened due to miniaturization of the body. The large asymmetry in leg dimensions on the left

322 and right sides of the body (Tab. 2D) and distinctly larger left maxillary palpomere (Tab. 2B) are

323 also evidence of nonstandard evolution of the genus Anaplecta."

The coriaceous tegmina are not sclerotized completely enough to be considered as elytrised, which is also seen in living $A$. maronensis.

In respective descriptions of living Mexican species the data about the ecology of

327 Anaplecta are missing. The diversity of the genus is very high in rainforest areas. Evangelista et al. (2015) highlight 4 species in Amazonas (Venezuela), 4 species in Guyana, 10 species in Suriname, 9 species in French Guiana, 10 species in Ampa (Brazil); Vidlička (2013) mentions 10 species in Ecuador; 8 species (including the new species) are known from Mexico based on the works of Saussure $(1862,1868,1869)$ and Hebard (1921).

The genus Anaplecta has presently a circumtropical distribution, and the (sub)tropical climate supports the newly described species as well. Fossil Anaplecta species are also known from Eocene Baltic Kaliningrad and Chinese ambers - the climate during Eocene in these areas was subtropical (Grimaldi 1996), and from the related Dominican amber (nevertheless, the Dominican species are undescribed and taxonomical placement needs confirmation - see above). American fauna (major locality Green River, Colorado, U.S.A. but also more northern localities in Canada - Greenwood at al. 2005, Archibald and Mathewes 2000) and also the Miocene fauna of Chiapas amber was cosmopolitan, while younger Dominican amber contains modern, 
341 American cockroach taxa - strongly suggesting a major extinction between these two time

342 periods (of deposition of these two sites - Vršanský et al. 2011). The present study cannot reveal

343 information on whether Anaplecta, inhabiting Americas today, is a native trace of the original

344 Eocene diversity or a descendant of a more recent re-invasion. This research awaits future

345 investigation..

positioned the Anaplectidae into one clade together with Tryonicidae, Cryptocercidae and morphological and taphonomical (i.e., absence in the rich Mesozoic record counting 30,000 sedimentary and over 3,000 amber specimens) observations, Anaplecta is a modern (plesiomorphy such as non-fully elytrised tegmina of the present species are also shared with some living representatives - see above) and developed genus typical of the Cenozoic. evolution (Huber et al. 2007), it is even part of the original ground plan in the whole order Dictyoptera. Asymmetries in left-right axis of other body parts can be also found among insects

356 (Smith et al. 1997). The fluctuating asymmetry can predict developmental instability of the individual (Dongen, 2006). In that case, the studied individual was vital and the unevenness of certain body parts did not affect the fitness or if it did, not fatally. The difference between left and right hind legs is neglectable (Femur $(\mathrm{F})=1.014[\mathrm{r}] /$ Tibia $(\mathrm{T})=1.12[\mathrm{r}] /$ Tarsomere $(\mathrm{Ta})$ $1=1.08[1] / \mathrm{Ta} 2=1 / \mathrm{Ta} 3=1 / \mathrm{Ta} 4=1 / \mathrm{Ta} 5=1)$. It explains the importance of the hind leg in the movement (Hughes, 1951). In contrast, the front femur leg (also important in the movement) is

362 highly asymmetrical. The biggest difference can be found between the left and right femur (the 363 left femur is almost twice as big). Also, the overall asymmetry is more evident $(\mathrm{F}=1.93[1] /$ 
$364 \mathrm{~T}=1.2[1] / \mathrm{Ta} 1=1.03[\mathrm{r}] / \mathrm{Ta} 2=1.14[\mathrm{r}] / \mathrm{Ta} 3=1 / \mathrm{Ta} 4=1.16[1] /$ Ta5=1.81[r]). The most asymmetrical

365 tarsomeres can be observed in the middle leg $(\mathrm{F}=1.41[1] / \mathrm{T}=1.25[1] / \mathrm{Ta} 1=1.65[\mathrm{r}] /$

$366 \mathrm{Ta} 2=1.71[\mathrm{r}] / \mathrm{Ta} 3=1.33[\mathrm{r}] / \mathrm{Ta} 4=1.75[1] / \mathrm{Ta} 5=1.63[\mathrm{r}])$.

The expansion of extremities longitudinally could have been caused post mortem, by

368

369

370 tension of polymerizing resin. The structure of resin can be modified due to conditions such as temperature, humidity change, etc. These changes can affect the state of preservation of the inclusion (Poinar \& Mastalerz, 2000).

The irregularity in length of extremities could have also happened while attempting to escape after being embedded in resin, which often even leads to disarticulation (MartínezDelclòs et al. 2004).

\section{CONCLUSIONS}

The Miocene cockroach Anaplecta vega sp.n. represents an extinct species of an extant genus and is consistent with a cosmopolitan pattern of Cenozoic occurrences. Its closest relatives live in South America, with which it shares the pronotum shape, tegmina shape and venation, and hind wing folding. Since the living representatives of Anaplecta prefer warm climates, Anaplecta vega probably also lived in warm (sub)tropical areas. It is the second cockroach species described from Chiapas amber, Mexico and belongs to the subfamily Anaplectinae, family Ectobiidae. The described individual shows noticeable asymmetries in maxillary palpomeres length, right cercus and some leg segments. The asymmetry regarding the genotypic or phenotypic origin remains obscure and needs further study. 
386

387

388

402

403

404

405

ANISYUTKIN. L. N. 2008. Paraeuthyrrhapha groehni gen. et sp. nov., a new genus of the family Polyphagidae (dictyoptera) from Baltic amber and its phylogenetical position. Alavesia 2, $77-85$

ANisYutKin, L.N. \& GOROCHOV, A.V. 2008. A new genus and species of the cockroach family Blattulidae from Lebanese amber (Dictyoptera, Blattina). Paleontological Journal 42(1), 44-47.

ANISYUTKIN, L.N. \& GRÖHN, C. 2012. New cockroaches (Dictyoptera: Blattina) from Baltic amber, with the description of a new genus and species: Stegoblatta irmgardgroehni. Trudy Zoologicheskogo Instituta 316(3), 193-202.

ARChiBALD, S.B, MATHEWES, R.W. 2000. Early Eocene insects from Quilchena, British Columbia, and their paleoclimatic implications. Canadian Journal of Zoology 78(8), 14411462.

Bai, M., Beutel, R.G., Klass, K.D., Zhang, W., YAnG, X. \& WiPfler, B. 2016. †Alienoptera - A new insect order in the roach-mantodean twilight zone, Gondwana Research 39, 317-326.

Bai., M., Beutel, R. G., Zhang, W., Wang, S., HöRnig, M., Gröhn, C., Yan, E., Yang, X., WIPLFLER, B. 2018 New Cretaceous Insect with a Unique Cephalo-thoracic Scissor Device. Current Biology 28(3), 438-443.

BeCCALONI, G.W. 2014. Cockroach Species File Online. Version 5.0/5.0. World Wide Web electronic publication. $<$ http://Cockroach.SpeciesFile.org $>$ [accessed 06 February 2017]. 
406 Berendt, G.C. 1836. Memoire pour servir a l'histoire des Blattes Antediluviennes. Annales de la $407 \quad$ Societe Entomologique de France (Serie 1), 5, 539-546.

408

409

410

411

412

413

414

415

416

417

418

419

420

421

422

423

424

425

BrunNer von WAttenwyl, C. 1865. Nouveau Systume des Blattaires. 426 pp. Vienna, Austria.

BurmeIster, H. 1938. Handbuch der Entomologie, vol. 2, part 2 a. 312 pp. G. Reimer, Berlin.

CAlisto, V., PiÑEIRo, G. 2019. A large cockroach from the mesosaur-bearing KonservatLagerstatte (Mangrullo Formation), Late Paleozoic of Uruguay. PeerJ e6289.

Cui, Y., Evangelista, D., BÉThOuX, O. 2018. Prayers for fossil mantis unfulfilled:

Prochaeradodis enigmaticus Piton, 1940 is a cockroach (Blattodea). Geodiversitas 10, $355-362$.

Cockerell, T.D.A. 1920. Fossil Arthropods in the British Museum, I. Annals and Magazine of Natural History (series 9) 5, 273-279.

DJernaes, M., Klass, K.D. \& EgGleton, P. 2014. Identifying possible sister groups of Cryptocercidae + Isoptera: A combined molecular and morphological phylogeny of Dictyoptera. Molecular Phylogenetics and Evolution 84, 284-303.

Dongen, S.V. 2006. Fluctuating asymmetry and developmental instability in evolutionary biology: past, present and future. Journal of Evolutionary Biology 19, 1727-1743.

Evangelista, D.A., Chan, K., Kaplan, K.L., Wilson, M.M. \& Ware, J.L. 2015. The Blattodea s.s. (Insecta, Dictyoptera) of the Guiana Shield. Zookeys 457, 37-87.

Foottit, R., AND PETER H. Adler. 2009. Insect biodiversity: science and society. Chichester, UK: Wiley-Blackwell. 
426 Foster, B. 1891. Die Insekten des "plattigen Steinmergels" von Brunnstatt. Abhandlungen zur 427 geologischen Spezialkarte von Elsass-Lothringen 3, 333-594.

428 GERMAR, E.F. 1813. Insekten in Bernstein eingeschlossen, beschrieben aus dem academischen Mineralien-Cabinet zu Halle. Magazin der Entomologie 1, 11-18.

Germar, E.F. \& BERENDT, G.C. 1856. Die im Bernstein befindlichen Hemipteren und Orthopteren der Vorwelt, 1-40. In BERENDT, G.C. (ed.) Die im Bernstein befindlichen organischen Resten der Vorwelt. Berlin.

GieBEL, C.G.A. 1856. Fauna der Vorwelt, Bd II. Die Insecten und Spinnen der Vorwelt. 511 pp., F.U. Brodhaus, Leipzig.

GIEBEL, C.G.A. 1862. Wirbelthier- und Insektenreste im Bernstein. Zeitschrift fbr die gesammten Naturwissenschaften 2(1), 311-322.

GoroKhov, A.V. 2007. New and Little Known Orthopteroid Insects (Polyneoptera) from Fossil Resins: Communication 2. Paleontological Journal 41(2), 156-166.

Gorokhov, A. V., AnisyutKin, L. N. 2007. Taxonomic names, in New and little known orthopteroid insects (Polyneoptera) from fossil resins: communication 2. Paleontological Journal 41, 156-166.

GREENWALT, D.E. \& VIDLIČKA, L. 2015. Latiblattella avita sp. nov. (Blattaria: Ectobiidae) from the Eocene Kishenehn Formation, Montana, USA. Palaeontologia Electronica 18, 1.

Greenwood, G.R., Archibald, S.B., Mathewes, R.W. \& Moss, P.T. 2005. Fossil biotas from the Okanagan highlands, southern British Columbia and northeastern Washington state: 

42(2), 167-185.

448

450

451

452

453

454

455

456

457

458

459

460

461

462

Grimaldi, D.A. 1996. Amber: Window to the Past: Harry N. Abrams, American Museum of Natural History. 216 pp.

GRIMALDI, D.A. \& Ross, A.J. 2004. Raphidiomimula, an enigmatic new cockroach in Cretaceous amber from Myanmar (Burma) (Insecta: Blattodea: Raphidiomimidae). Journal of Systematic Palaeontology 2(2), 101-104.

GutiÉRrez, E. \& PÉREZ-Gelabert, D.E. 2000. Annotated Checklist of Hispaniolan Cockroaches. Transactions of the American Entomological Society 126(3/4), 423-446.

HAUPT, H. 1956. Beitrage zur Kenntuis der еozдnen Arthropodenfauna des Geiseltales. Nova Acta Leopoldina NS 18, 1-90.

HeBARD, M. 1921. Mexican records of Blattidae (Orthoptera). Transactions of the American Entomological Society 47(3), 199-220.

HeER, O. 1849. Die Insektenfauna der Tertiargebilde von Oeningen und von Radoboj in Croatien Vol 2. Heuschreken, Florfliegen, Alderflugen, Schmetterlinge, und Fliegen. 264 pp. Engelmann, Leipzig.

HEER, O. 1864. Die Urwelt der Schweiz. 366 pp. Friedrich Schulthess, Zurich.

HeER, O. 1868. Fossile Insecten von Nordgrönland. Flora Fossilis Arctica: Die Fossile Flora der Polarländer 1, 129-130. 
465 HeEr, O. 1870. Die Miocene Flora und Fauna Spitzbergens. Mit einen Anhang uber die

466 Diluvialen Ablagerungen Spitzbergens. Kongliga Svenska Vetenskapsakademiens

467 Avhandlingar I Naturskyddsarenden 8(7), 1-98.

468 HeYden, C.H.G. von. 1862. Gliedertiere aus der Braunkohle des Niederrheins, der Wetterau und 469 der Rhon. Palaeontographica 10, 62-82.

470 Hörnig, M.K., SombKe, A., Haug, C., Harzsch, S. \& Haug, J.T. 2016. What nymphal morphology can tell us about parental investment - a group of cockroach hatchlings in

Hong, Y.C. 2002. Amber Insects of China [In Chinese]. 653 pp. Scientific and Technical Baltic amber documented by a multi-method approach. Palaeontologia electronica 19, 1,

Huber, B. A., Sinclair, B. J. \& Schmitt, M. 2007. The evolution of asymmetric genitalia in spiders and insects. Biological Reviews 82(4), 647-698.

Hughes, G. M. 1952. The Co-ordination of Insect Movements. Journal of Experimental Biology $29,267-285$.

KoČÁREK, P. 2018a. Alienopterella stigmatica gen. et sp. nov.: the second known species and specimen of Alienoptera extends knowledge about this Cretaceous order (Insecta: Polyneoptera). Journal of Systematic Palaeontology https://doi.org/10.1080/ 14772019.2018 .1440440$.

KoČÁREK, P. 2018b. The cephalo-thoracic apparatus of Caputoraptor elegans may have been used to squeeze prey. Current Biology 28(15), 824-825. 
486 Solórzano Kraemer, M. M., Delclòs, X., Clapham, M. E., Arillo, A., Peris, D., Jäger, P., 487 SteBner, F., PEÑAlVer, E. 2018. Arthropods in modern resins reveal if amber accurately recorded forest arthropod communities. PNAS 115, 6739-6744.

Legendre, F., Nel, A., Svenson, G.J., Robillard, T., Pellens, R., Grandcolas, P. 2015. Phylogeny of Dictyoptera: Dating the Origin of Cockroaches, Praying Mantises and Termites with Molecular Data and Controlled Fossil Evidence. PLoS One 10(7): e0130127.

LI, X.-R., HuANG, D. 2018. A new Cretaceous cockroach with heterogeneous tarsi preserved in Burmese amber (Dictyoptera, Blattodea, Corydiidae). Cretaceous Research 92, 12-17.

Martínez-Delclòs, X., Briggs, D.E.G. \& PeÑAlver, E. 2004. Taphonomy of insects in carbonates and amber. Palaeogeography Palaeoclimatology Palaeoecology 203(1-2), 1964.

Maekawa, K., Lo, N., Rose, H.A. \& Matsumoto, T. 2003. The evolution of soil-burrowing cockroaches (Blattaria : Blaberidae) from wood-burrowing ancestors following an invasion of the latter from Asia into Australia. Proceedings of the Royal Society B-Biological Sciences 270(1521), 1301-1307.

MeunIER, F. 1921. Die Insektenreste aus dem Lutetien von Messel bei Darmstadt. Abhandlungen der Hessischen geologischen Landesanstalt zu Darmstadt 7(3), 2-15.

MlynskÝ, T., Wu, H., KoubOvÁ, I., 2018. Dominant Burmite cockroach Jantaropterix ellenbergeri sp.n. might laid isolated eggs together. Paleontographica Abteilung A 311. https://doi.org/10.1127/pala/2019/0091. 
506 Najarro, M., Penalver, E., Rosales, I., Perez-De La Fuente, R., Daviero-Gomez, V. \& 507 Delclos X. 2009. Unusual concentration of Early Albian arthropod-bearing amber in the 508 Basque-Cantabrian Basin (El Soplao, Cantabria, Northern Spain): Palaeoenvironmental 509 and palaeobiological implications. Geologica Acta 7(3), 363-387.

ORUŽINSKÝ, R., VRŠANSKÝ, P. 2017. Cockroach forewing area and venation variabilities relate. Biologia 72(7), 814-818.

PERRICHOT, V. 2004. Early Cretaceous amber from south-western France: insight into the Mesozoic litter fauna. Geologica Acta 2(1), 9-22.

Piton, L.E. 1936. Les Orthopteres tertiaires d'Auvergne. Miscellanea Entomologica 37, 77-79.

515

516

517

518

519

520

Piton, L.E. 1940. Paleontologie du gisement eocene de Menat (Puy-de-Dom) (Flore et Faune). Memoires de la Societe d'Histoire Naturelle d'Auvergne 1, 1-303.

PodstrelenÁ, L., SENDi, H. 2018. Cratovitisma Bechly, 2007 (Blattaria: Umenocoleidae) recorded in Lebanese and Myanmar ambers. Palaeontographica Abteilung A 310(3-6), 121-129.

PoINAR G. JR. 1992: Life in Amber. Stanford University Press, Stanford, 1-350.

PoINAR, G. JR. \& BROWN, A.E. 2017. An exotic insect Aethiocarenus burmanicus gen. et sp. nov. (Aethiocarenodea ord. nov., Aethiocarenidae fam. nov.) from mid-Cretaceous Myanmar amber. Cretaceous Research 72, 100-104.

Poinar, G. JR., Mastalerz, M., 2000. Taphonomy of fossilized resins: Determining the biostratinomy of amber. In: Martínez-Delclòs, X., Nel, A. (Eds.), Studies on Mesozoic and 
526

527

528

529

530

531

532

533

534

535

536

537

538

539

540

541

542

543

544

545

546

Tertiary Insects: Systematics, Phylogeny and Taphonomy. Acta Geologica Hispanica 35, 171-182.

PoinAR, G. JR., BuCKLEY, R. 2006. Nematode (Nematoda: Mermithidae) and hairworm (Nematomorpha: Chordodidae) parasites in Early Cretaceous amber. Journal of Invertebrate Pathology 93(1), 36-41.

POINAR, G. JR. 2009. Early Cretaceous protist flagellates (Parabasalia: Hypermastigia: Oxymonada) of cockroaches (Insecta: Blattaria) in Burmese amber. Cretaceous Research 30(5):1066-1072.

PrinCIS, K. 1962. Blattariae: Subordo Polyphagoidea: Fam. Polyphagidae, 1-74. In: BEIER, M. (ed.) Orthopterorum Catalogus, Pars 3. W. Junk's-Gravenhage.

PRINCIS, K. 1963 Blattariae: Suborde [sic] Polyphagoidea: Fam.: Homoeogamiidae, Euthyrrhaphidae, Latindiidae, Anacompsidae, Atticolidae, Attaphilidae. Subordo Blaberoidea: Fam. Blaberidae, 76-172. In: BEIER, M. (ed.) Orthopterorum Catalogus, Pars

PrINCIS, K. 1964. Blattariae: Subordo Blaberoidea: Fam.: Panchloridae, Gynopeltididae, Derocalymmidae, Perisphaeriidae, Pycnoscelididae, 174-281. In: BEIER, M. (ed.), Orthopterorum Catalogus, Pars 6. W. Junk, 's-Gravenhage.

PRINCIS, K. 1965. Blattariae: Subordo Blaberoidea: Fam.: Oxyhaloidae, Panesthiidae, Cryptocercidae, Chorisoneuridae, Oulopterygidae, Diplopteridae, Anaplectidae, Archiblattidae, Nothoblattidae, 284-400. In: BEIER, M. (Ed.), Orthopterorum Catalogus, Pars 7: $W$. Junk, 's-Gravenhage. 
547 Princis, K. 1966. Blattariae: Suborbo [sic] Blattoidea. Fam.: Blattidae, Nocticolidae, 402-614.

548 In: BeIER, M. (ed.), Orthopterorum Catalogus, Pars 8. W. Junk, 's-Gravenhage.

549 PRINCIS, K. 1967. Blattariae: Suborbo [sic] Epilamproidea. Fam.: Nyctiboridae, Epilampridae, 550 617-710. In: BEIER, M. (ed.), Orthopterorum Catalogus, Pars 11. W. Junk's-Gravenhage.

551 PRINCIS, K. 1969. Blattariae: Subordo Epilamproidea. Fam.: Blattellidae, 712-1038. In: BEIER, 552 M. (ed.), Orthopterorum Catalogus, Pars 13. W. Junk, 's-Gravenhage.

553 PRINCIS, K. 1971. Blattariae: Subordo Epilamproidea. Fam.: Ectobiidae, 1041-1224. In: BEIER, 554 M. (Ed.), Orthopterorum Catalogus, Pars 14. W. Junk, 's-Gravenhage.

555 QIU, L., WANG, Z.-Q., CHE, Y.-L. 2019a. A new corydiid cockroach with large holoptic eyes in 556 Upper Cretaceous Burmese amber (Blattodea: Corydiidae: Euthyrrhaphinae). Cretaceous $557 \quad$ Research 96, 179-183.

558 QIU, L., WANG, Z.-Q., CHE, Y.-L. 2019b. First record of Blattulidae from mid-Cretaceous 559 Burmese amber (Insecta: Dictyoptera). Cretaceous Research 99, 281-290.

RENTZ, D. C. 2014. A Guide to the Cockroaches of Australia. 326pp. CSIRO Publishing. $561 \quad$ Collingwood.

562 SAussure, H. de 1862. Orthoptera Nova Americana (Diagnoses praeliminares). Series III. Revue 563 et Magasin de Zoologie Pure et Applique 2(14), 163-171, 227-234.

564 SAUSSURE, H. de 1868. Orthopterorum species novae aliquot. Revue et Magasin de Zoologie 565 Pure et Appliquée 2(20), 97-101, 354-357. 
566 SAussure, H. de 1869.Mélanges Orthoptérologiques . II ${ }^{\text {me }}$ Fascicule. Memoires de la Société de

567 Physique et d'Histoire Naturelle de Genève20, 227-326.

568 SCUDDER, S.H. 1876. Brief synopsis of North American earwigs with an appendix on the fossil

569 species. Bulletin of the United States Geological and Geographical surveys of the

$570 \quad$ Territories 2, 249-260.

571 ScudDER, S.H. 1890. The Tertiary insects of North America. Report of the United States

572 Geological Survey of the Territories 13, 1-734.

573 SENDI, H. \& AzAR, D. 2017. New aposematic and presumably repellent bark cockroach from

$574 \quad$ Lebanese amber. Cretaceous Research 72, 13-17.

575 SidorchuK, E. A., Khaustov, A. A. 2018. A parasite without host: The first fossil

576 pterygosomatid mite (Acari: Prostigmata: Pterygosomatidae) from French Lower

$577 \quad$ Cretaceous amber. Cretaceous Research 91, 131-139.

578 Smith, D. R., Crespi, B. J., Bookstein, F. L. 1997. Fluctuating asymmetry in the honey bee, 579 Apis mellifera: effects of ploidy and hybridization. Journal of Evolutionary Biology 10, $580 \quad 551-574$.

581 SOlÓRZANO-KRAEMER, M.M.S. 2007. Systematic, palaeoecology, and palaeobiogeography of

582 the insect fauna from Mexican amber. Paleontographica Abteilung A 282, 1-6, 1-133.

583 StAтZ, G. 1939. Geradflugler und Wasserkдfer der Oligocanen Ablagerungen von Rott".

584 Decheniana A: Geologische Abteilung 99, 1-102.

585 ŠMíDOVÁ, L. \& LEI, X. 2017. The earliest amber-recorded type cockroach family was aposematic 586 (Blattaria: Blattidae). Cretaceous Research 72, 189-199. 
587 Vega, F.J.T., Nyborg T., Coutino, M.A., Solŭ, J. \& HernbndeZ-Monzyn, O. 2009. Neogene 588 Crustacea from southeastern Mexico. Bulletin of Mizunami Fossiil Museum 35, 51-69.

589 VIDLIČKA, L'. 2013. Cockroaches (Blattaria) of Ecuador - checklist and history of research. $590 \quad$ Zootaxa 3599(5), 401-445.

591 Vidlǐ́Ka, L, VRŠanský, P., Kúdelová, T., Kúdela, M., Deharveng, L. \& Hain, M. 2017. 592 New genus and species of cavernicolous cockroach (Blattaria, Nocticolidae) from Vietnam. $593 \quad$ Zootaxa 4232(3), 361-375.

594 VRŠANSKÝ, P. 1997. Piniblattella gen. nov.- the most ancient genus of the family Blattellidae 595 (Blattodea) from the Lower Cretaceous of Siberia. Entomological Problems 28, 67-79.

596 VRŠANSKÝ, P. 2002. Origin and Early Evolution of Mantises. Amba projekty 6(1), 1-16.

597 VRŠANSKÝ, P. 2004. Cretaceous Gondwanian Cockroaches (Insecta, Blattaria). Entomological $598 \quad$ Problems 34 (1-2), 49-54.

VRŠANSKÝ, P. 2008a. Mesozoic relative of the common synanthropic German cockroach 600 (Blattodea). Deutsche Entomologische Zeitschrift 55(2), 215-221.

601

602

603

604 605

VRŠANSKÝ, P. 2008b. A complete larva of a Mesozoic (Early Cenomanian) cockroach (Inesecta: Blattaria: Blattulidae) from the Sisteron amber (Alpes de Haute Provence, SE France). Geologica Carpathica 59(3), 269-272.

VRŠANSKÝ, P. 2009. Albian cockroaches (Insecta, Blattida) from French amber of Archingeay. Geodiversitas 31(1), 73-98. 
606 VRŠANSKÝ, P. 2010. Cockroach as the earliest eusocial animal. Acta Geologica Sinica (english $607 \quad$ edition) $84(4), 793-808$.

608 VRŠANSKÝ, P. \& ARISTOV, D. 2014. Termites (Isoptera) from the Jurassic/Cretaceous boundary: 609 Evidence for the longevity of their earliest genera. European Journal of Entomology $610 \quad 111(1), 137-141$.

611 VRŠANSKÝ, P. \& BECHLY, G. 2015. New predatory cockroaches (Inseta: Blattaria:

612 Manipulatoridae fam.n.) from the Upper Cretaceous Myanmar amber. Geologica $613 \quad$ Carpathica 66(2), 133-138.

614 VrŠAnskÝ, P., Cifuentes-Ruiz, P., VidliČKa, j., ČiAMPOR jr, F.J. \& VegA, F.J. 2011. Afro615 Asian cockroach from Chiapas amber and the lost Tertiary American entomofauna. $616 \quad$ Geologica Carpathica 62(5), 463-475.

617 VRŠAnskÝ, P., ChORVÁt, D., Fritzsche, I., HAIN, M. \& ŠEVČÍK R. 2012a. Light-mimicking 618 cockroaches indicate Tertiary origin of recent terrestrial luminescence.

$619 \quad$ Naturwissenschaften 99(9), 739-749.

620 VRŠANSKÝ, P., VIDLIČKA, j., ČIAMPOR, F. Jr. \& MARSH, F. 2012b. Derived, still living 621 cockroach genus Cariblattoides (Blattida: Blattellidae) from the Eocene sediments of Green 622 River in Colorado, USA. Insect Science 19(2), 143-152.

623 VrŠAnskÝ, P., VidličKa, j., Barna, P., Bugdaeva, E., \& MarkeVich, V. 2013a. Paleocene 624 origin of the cockroach families Blaberidae and Corydiidae: Evidence from Amur River 625 region of Russia. Zootaxa 3635(2), 117-126. 
626 VrŠanský, P., Van de Kamp, T., Azar, D., Prokin, A., VidličKa, L. \& Vagovič, P. 2013 b.

627 Cockroaches probably cleaned up after dinosaurs. PLOS ONE 8(12), AN e80560.

628 VRŠAnSKÝ, P., ORUŽInSKÝ, R., BARNA, P., VIDLIČKA, j. \& LABANDEIRA, C. C. 2014. Native 629 Ectobius (Blattaria: Ectobiidae) From the Early Eocene Green River Formation of 630 Colorado and Its Reintroduction to North America 49 Million Years Later. Annals of the 631 Entomological Society of America 107(1), 28-36.

632

633

634

635

636

637

638

639

640

641

642

643

644

645

VRŠANSKÝ, P. \& LABANDEIRA, C. (In Press) Early-derived Eocene Cockroaches (Blattaria: Ectobiidae: Pseudophyllodromiinae, Blattelinae) from the Green River Formation, Colorado, U.S.A. Proceedings of the Entomological Society of Washington.

VRŠAnSKÝ, P.V., ŠMídOVÁ, L., VALAŠKA, D., BARNA, P., VidLičKA, L., TAKÁČ, P., PAVLIK, L., KúdelovÁ, T., KARIM, T.S., ZELAGIN, D., SMITH, D. 2016. Origin of origami cockroach reveals long-lasting (11 Ma) phenotype instability following viviparity. Naturwissenschaften 103(9-10), 78.

VRŠANSKÝ, P., WANG, B. 2017. A new cockroach, with bipectinate antennae, (Blattaria: Olidae fam. nov.) further highlights the differences between the Burmite and other faunas. Biologia 72(11), 1327-1333.

VRŠAnský, P., ŠmídovÁ, L., Sendi, H., BARna, P., Müller, P., Ellenberger, S., Wu, H., Ren, X., Lei, X., AzAr, D., Šurka, J., Su, T., Deng, W., Shen, X., Lv, J., BaO, T., Bechly, G. 2018a. Parasitic cockroaches indicate complex states of earliest proved ants. Biologia https://doi.org/10.2478/s11756-018-0146-y. 
646 VRŠAnSKÝ, P., BECHLY, G., ZhANG, Q., JARZEMBOWSKI, E.A., MLYNSKÝ, T., ŠMÍDOVÁ, L., 647 Barna, P., Kúdela, M., Aristov, D., Bigalk, S., Krogmann, L., Li, L., Zhang, Q., Zhang, H., Ellenberger, S., Müller, P., Gröhn, C., XiA, F., UedA, K., VĎaČnÝ, P., VALAŠKA, D., VRŠANSKÁ, L., WANG, B. 2018b. Batesian insect-insect mimicry-related 650 explosive radiation of ancient alienopterid cockroaches. Biologia 73(10), 987-1006.

651

652

653

654
VRŠANSKÝ, P., VRŠANSKÁ, L., BeŇO, M., Tong, B., LEI, X., REN, X., Wu, H., ŠMíDOVÁ, L., Bechly, G., Jun, L., YeO, M., Jarzembowski, E. 2018c. Pathogenic DWV infection symptoms in a Cretaceous cockroach. Paleontographica Abteilung A https://doi.org/10.1127/0375- 0442/2018/0000/008 (in press).

VrŠAnskÝ, P., Sendi, H., Aristov, D., Bechly, G., Müller, P., Ellenberg, S., AzAr, D., UEDA, K., BARnA, P., GARCIA, T. 2019. Ancient roaches further exemplify 'no land return' in aquatic insects. Gondwana Research (68), 22-33.WALKER, F. 1868. Catalogue of the Specimens of Blattaria in the Collection of the British Museum, 239 pp. British Museum, London, UK.

Zhang, J.F., Liu, D., Shangguan, Y. 1989. Fossil insects from Shanwang, Shandong, China. [Chinese with English abstract], 459 pp. Shandong Science and Technology Publishing House, Jinan, China.

ZHANG, J.F., Sun, B. \& ZHANG, X. 1994. Miocene Insects and spiders from Shanwang, Shandong. [In Chinese, English summary], 298 pp. Science Press Beijing, Beijing.

Zhang, Z.J., SchneIDER, J.W. \& Hong, Y.Q. 2012. The most ancient roach (Blattida): A new genus and species from the earliest Late Carboniferous (Namurian) of China, with 
667 discussion on the phylomorphogeny of early blattids. Journal of Systematic Paleontology, $668 \quad 11(1), 27-40$.

669 Link for the specimen records "MNHN-EP-EP1398" and "MNHN-EP-EP1385" [available on $67018 / 11 / 2018]$ here:

671 https://science.mnhn.fr/institution/mnhn/collection/ep/item/ep1398?lang=en_US.

672 https://science.mnhn.fr/institution/mnhn/collection/ep/item/ep1385.

673 


\section{Figure 1}

Photos of amber inclusion and map of destribution of genus Anaplecta spp.

(A) Partial 3D extraction. (B) Ventral view. (C) Dorsal view. (D) Whole piece of amber, ventral view. Specimen overall length head-abdomen, $4.89 \mathrm{~mm}$. (E) Distribution map of amber Anaplecta spp. with the Baltic amber reaching out of the present range. 

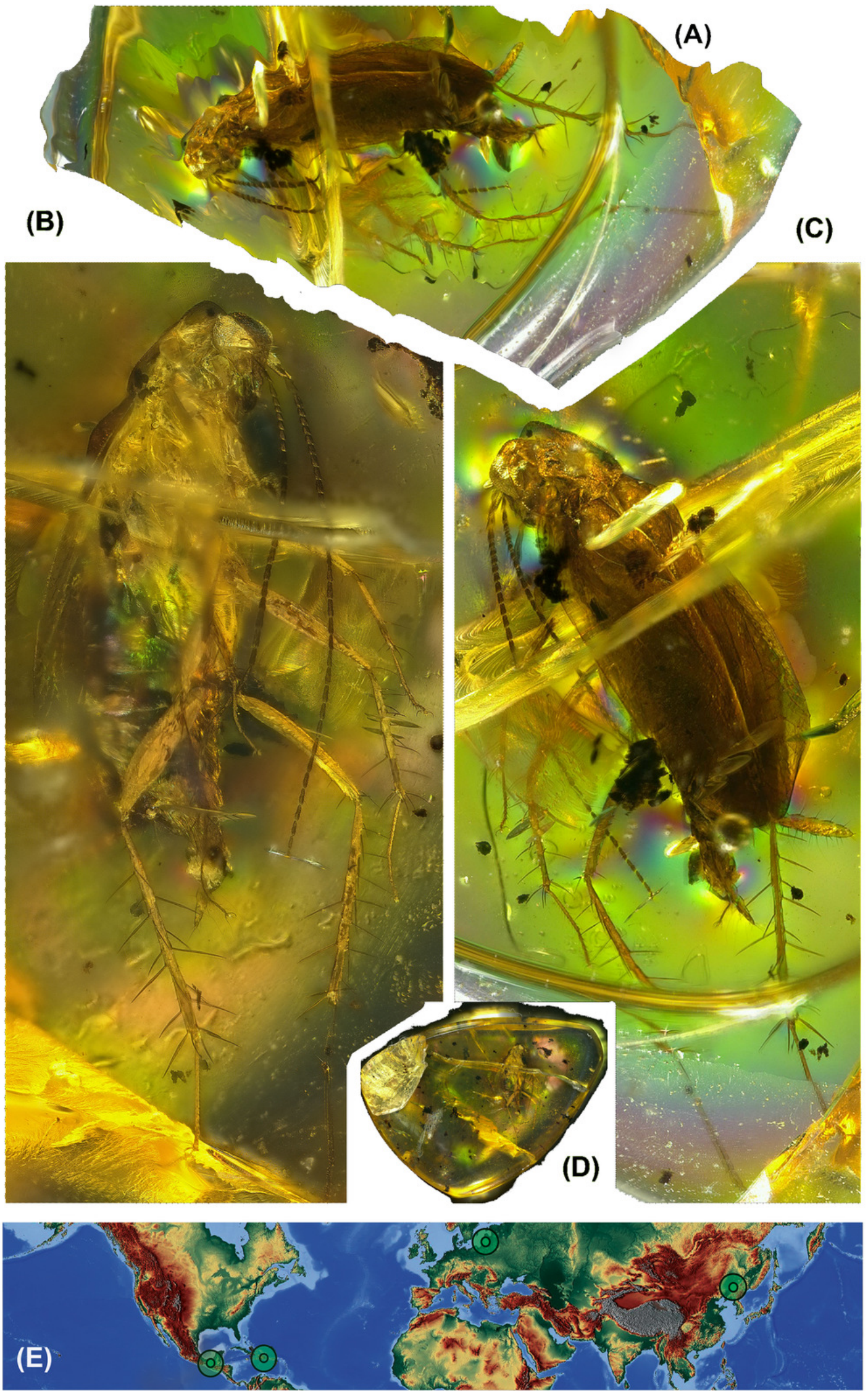
Figure 2

Line drawing of Anaplecta vega sp.n. 


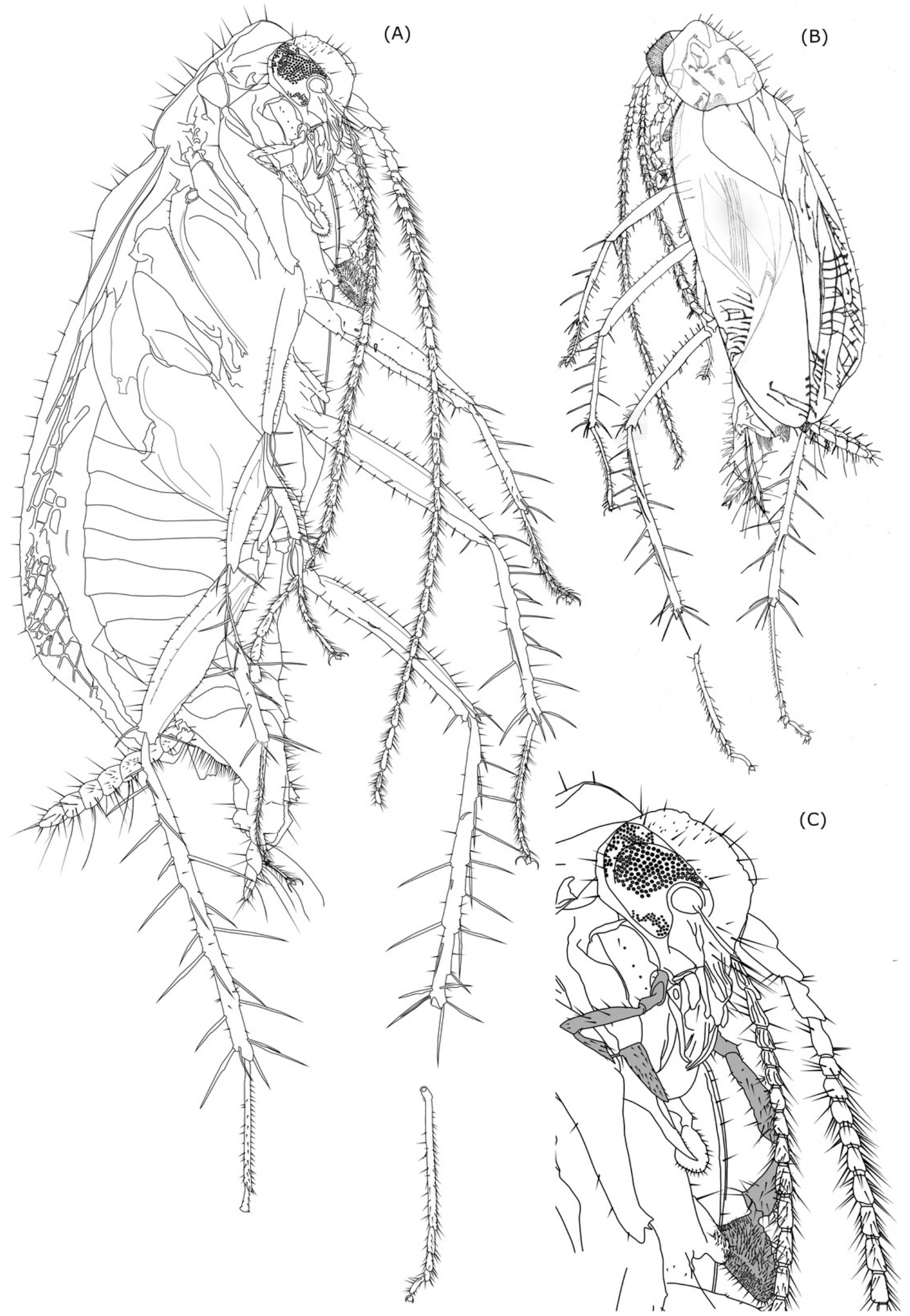




\section{Table $\mathbf{1}$ (on next page)}

List of Cenozoic cockroaches with respective literature.

1- Germar (1813), 2- Berendt (1836), 3- Heer (1849), 4- Germar \& Berendt (1856), 5- Giebel (1856), 6- Giebel (1862), 7- Heyden (1862) 8- Heer (1864), 9- Heer (1868), 10-, Heer (1870), 11- Scudder (1876), 12- Scudder (1890), 13- Foster (1891), 14- Cockerell (1920), 15- Meunier (1921), 16- Piton (1936), 17- Statz (1939), 18- Piton (1940), 19- Haupt (1956), 20- Zhang (1989), 21- Zhang et al. (1994), 22- Hong (2002), 23- Maekawa et al. (2003), 24- Gorokhov et Anisyutkin (2007), 25- Anisyutkin (2008), 26- Vršanský et al. (2011), 27- Vršanský et al. (2012a), 28- Vršanský et al. (2012b), 29- Vršanský et al. (2013a), 30- Vršanský et al. (2014), 31- Vršanský et al. (2016), 32- Anisyutkin \& Gröhn (2012), 33- Greenwalt \& Vidlička (2015), 34- Hörnig et al. (2016), 35-Ciu et al., (2018). 


\begin{tabular}{|c|c|}
\hline Species known from sediment & Species known from amber/copal \\
\hline Blaberites rhenana Statz $1939^{17}$ & Blatta baltica Germar et Berendt $1856^{4}$ \\
\hline Blatta colorata Heer $1864^{8}$ & B. berendti Giebel $1856^{5}$ \\
\hline B. hyperborea Heer $1870^{10}$ & B. didyma Germar et Berendt $1856^{4}$ \\
\hline B. pauperata Heyden $1862^{7}$ & B. elliptica Giebel $1862^{6}$ \\
\hline B.sundgaviensis Foster $1891^{13}$ & B. gedanensis Germar et Berendt $1856^{4}$ \\
\hline Blattidium fragile Heer $1868^{9}$ & B. ruficeps Giebel $1862^{6}$ \\
\hline $\begin{array}{l}\text { Cariblattoides labandeirae Vršanský et al. } \\
2011^{26,28}\end{array}$ & B. succinea Germar $1813^{1}$ \\
\hline Chopardia spinipes Piton $1940^{18}$ & $\begin{array}{l}\text { Erucoblatta semicaeca Gorokhov et } \\
\text { Anisyutkin } 2007^{24}\end{array}$ \\
\hline Diploptera Vladimir Vršanský $2016^{31}$ & $\begin{array}{l}\text { Holocompsa nigra Gorokhov et Anisyutkin } \\
2007^{24}\end{array}$ \\
\hline D. gemini Barna $2016^{31}$ & $\begin{array}{l}\text { H. abbreviata Gorokhov et Anisyutkin } \\
2007^{24}\end{array}$ \\
\hline D. savba Šmídová $2016^{31}$ & Latiblatta orientalis Hong $2002^{22}$ \\
\hline $\begin{array}{l}\text { Ectobia arverniensis Piton } 1940^{18} \\
\text { Eviewing PDF | (2018:02:25104:3:0:NEW } 5 \text { Sep 2019) }\end{array}$ & L. spinosa Hong $2002^{22}$ \\
\hline
\end{tabular}




\begin{tabular}{|c|c|}
\hline E. menatensis Piton $1940^{18}$ & Nyctibora elongate Statz $1939^{17}$ \\
\hline Ectobius glabellus Statz $1939^{17}$ & $\begin{array}{l}\text { Paraeuthyrrhapha groehni Anisyutkin } \\
2008^{25,32}\end{array}$ \\
\hline $\begin{array}{l}\text { E. kohlsi Vršanský, Oružinský, Barna, } \\
\text { Vidlička et Labandeira } 2014^{30}\end{array}$ & $\begin{array}{l}\text { Polyzosteria parvula Germar et Berendt } \\
1856^{4}\end{array}$ \\
\hline Elisama pyrula Zhang $1989^{20}$ & P. tricuspidata Berendt $1836^{2}$ \\
\hline "Gyna" obesa Piton $1940^{18}$ & $\begin{array}{l}\text { Supella (Nemosupella) miocenica } \\
\text { Vršanský, Cifuentes-Ruiz, Vidlička, } \\
\text { Čiampor et Vega } 2011^{26}\end{array}$ \\
\hline Heterogamia antiqua Heer $1849^{3}$ & $\begin{array}{l}\text { Stegoblatta irmgardgroehni Anisyutkin et } \\
\text { Gröhn } 2012^{32}\end{array}$ \\
\hline Homoeogamia ventriosa Scudder $1876^{11}$ & \\
\hline Isoplates longipennis Haupt $1956^{19}$ & \\
\hline $\begin{array}{l}\text { Latiblattella avita Greenwalt et Vidlička, } \\
2015^{33}\end{array}$ & \\
\hline $\begin{array}{l}\text { Morphna paleo Vršanský, Vidlička, Barna, } \\
\text { Bugdaeva et Markevich } 2013^{29}\end{array}$ & \\
\hline Paralatindia saussurei Scudder $1890^{12}$ & \\
\hline
\end{tabular}




\begin{tabular}{|l|l|}
\hline Parallelophora acuta Haupt $1956^{19}$ & \\
\hline P. anomala Haupt $1956^{19}$ & \\
\hline Periplaneta eocaenica Meunier $1921^{15}$ & \\
\hline P. houlberti Piton $1940^{18}$ & \\
\hline P. hylecoeta Zhang $1989^{20}$ & \\
\hline P. lacera Zhang $1989^{20}$ & \\
\hline P. relicta Meunier $1921^{15}$ & \\
\hline P. sphodra Zhang, Sun et Zhang $1994^{21}$ & \\
\hline Phantocephalus meridionalis Zhang $1989^{20}$ & \\
\hline Prochaeradodis enigmaticus Piton $1940^{18,35}$ & \\
\hline Protectobia primordialis Piton $1940^{18}$ & \\
\hline Protostylopyga gigantea Piton $1940^{18}$ & \\
\hline Pycnoscelus gardneri Cockerell $1920^{14}$ & \\
\hline Zeunera madeleinae Piton $1936^{16}$ & \\
\hline
\end{tabular}


2

3

4

5 


\section{Table 2 (on next page)}

Measurements of Anaplecta vega.

(A) Body measurements of Anaplecta vega sp.n. and different Anaplecta species. (B)

Comparison of Anaplecta vega sp.n. left and right maxillary palpomere lengths. (C)

Comparison of $A$. vega sp.n. dimensions and average of living Mexican Anaplecta species dimensions. (D) Comparison of length of each leg femur, tibia and tarsomeres of Anaplecta vega sp.n. (E) Left and right antennomeres length comparison including scape and pedicel present in Anaplecta vega sp.n. 
$1 \mathrm{~A}$

\begin{tabular}{|l|l|l|l|l|l|l|}
\hline & Body I & $\begin{array}{l}\text { Tegmin } \\
\text { a I }\end{array}$ & $\begin{array}{l}\text { Pronotu } \\
\mathrm{m} \mathrm{I}\end{array}$ & $\begin{array}{l}\text { Pronotu } \\
\mathrm{m} \mathrm{w}\end{array}$ & $\begin{array}{l}\text { Tegmina } \\
\text { I/pronotu } \\
\mathrm{m} \mathrm{I}\end{array}$ & $\begin{array}{l}\text { Pronotum } \\
\text { I/pronotu } \\
\mathrm{m} \mathrm{w}\end{array}$ \\
\hline $\begin{array}{l}\text { A. vega including } \\
\text { tegmina }\end{array}$ & 4,89 & 4,04 & 1 & 1,27 & 4,04 & 0,79 \\
\hline A. azteca & 6,5 & 5,8 & 2 & 2,5 & 2,9 & 0,8 \\
\hline A. fallax & 4,6 & 4 & 1,5 & 2,25 & 2,67 & 0,67 \\
\hline $\begin{array}{l}\text { A. decipiens male incl. } \\
\text { tegmina }\end{array}$ & 4,8 & 3,5 & 2 & 2,4 & 1,75 & 0,83 \\
\hline $\begin{array}{l}\text { A. decipiens female incl. } \\
\text { tegmina }\end{array}$ & 5,8 & 4,6 & 2 & 2,4 & 2,3 & 0,83 \\
\hline A. mexicana & 8 & 8,5 & 2 & 3,5 & 4,25 & 0,57 \\
\hline A. gemma & 6,7 & 6,8 & 1,7 & 2,3 & 4 & 0,74 \\
\hline A. nahus incl. tegmina & 6 & 5,5 & 1,5 & 2,4 & 3,67 & 0,63 \\
\hline A. otomia & 6,5 & 6 & 1,75 & 2,4 & 3,43 & 0,73 \\
\hline A. saussurei & 4,1 & 3,8 & 1,3 & 1,9 & 2,92 & 0,68 \\
\hline A. tolteca & 6 & 6,5 & 1,6 & 2,5 & 4,06 & 0,64 \\
\hline
\end{tabular}

2

3 B

\begin{tabular}{|l|l|l|}
\hline & Right maxillary palp & Left maxillary palp \\
\hline 1 & 0,13 & 0,13 \\
\hline 2 & 0,1 & 0,14 \\
\hline 3 & 0,31 & 0,4 \\
\hline 4 & 0,17 & 0,29 \\
\hline 5 & 0,27 & 0,34 \\
\hline
\end{tabular}

4

$5 \mathrm{C}$

\begin{tabular}{|l|l|l|}
\hline & $\begin{array}{l}\text { A. vega length } \\
\text { (including tegmina) }\end{array}$ & $\begin{array}{l}\text { Avarage Mexican } \\
\text { Anaplecta length }\end{array}$ \\
\hline Body I & 4,89 & 5,9 \\
\hline Tegmina I & 4,04 & 5,5 \\
\hline Pronotum I & 1 & 1,74 \\
\hline Pronotum w & 1,27 & 2,48 \\
\hline Tegmina I/pronotum I & 4,04 & 3,19 \\
\hline Pronotum I/pronotum w & 0,79 & 0,71 \\
\hline
\end{tabular}

6

7

8 
$9 \mathrm{D}$

\begin{tabular}{|l|l|l|l|l|l|l|}
\hline & Front L & Front R & Middle L & $\begin{array}{l}\text { Middle } \\
\text { R }\end{array}$ & Hind L & Hind R \\
\hline Femur & 1,29 & 0,67 & 1,29 & 0,91 & 1,38 & 1,4 \\
\hline Tibia & 0,89 & 0,73 & 0,89 & 1,11 & 1,89 & 2,13 \\
\hline Tarsomere 1 & 0,34 & 0,33 & 0,34 & 0,56 & 0,91 & 0,84 \\
\hline Tarsomere 2 & 0,07 & 0,08 & 0,07 & 0,12 & 0,19 & 0,19 \\
\hline Tarsomere 3 & 0,06 & 0,06 & 0,06 & 0,08 & 0,11 & 0,11 \\
\hline Tarsomere 4 & 0,07 & 0,06 & 0,07 & 0,04 & 0,1 & 0,1 \\
\hline Tarsomere 5 & 0,11 & 0,2 & 0,11 & 0,18 & 0,18 & 0,18 \\
\hline
\end{tabular}

10

$11 E$

\begin{tabular}{|l|l|l|}
\hline & $\begin{array}{l}\text { Left } \\
\text { antenna }\end{array}$ & Right antenna \\
\hline 1 & 0,33 & 0,29 \\
\hline 2 & 0,22 & 0,2 \\
\hline 3 & 0,16 & 0,16 \\
\hline 4 & 0,09 & 0,09 \\
\hline 5 & 0,09 & 0,07 \\
\hline 6 & 0,09 & 0,07 \\
\hline 7 & 0,09 & 0,1 \\
\hline 8 & 0,1 & 0,1 \\
\hline 9 & 0,11 & 0,12 \\
\hline 10 & 0,12 & 0,11 \\
\hline 11 & 0,12 & 0,12 \\
\hline 12 & 0,13 & 0,14 \\
\hline 13 & 0,14 & 0,13 \\
\hline 14 & 0,14 & 0,14 \\
\hline 15 & 0,14 & 0,13 \\
\hline 16 & 0,14 & 0,14 \\
\hline 17 & 0,16 & 0,16 \\
\hline 18 & 0,16 & 0,16 \\
\hline 19 & 0,16 & 0,16 \\
\hline 20 & 0,16 & 0,14 \\
\hline 21 & 0,14 & 0,17 \\
\hline 22 & 0,17 & 0,17 \\
\hline 23 & 0,18 & 0,17 \\
\hline 24 & 0,17 & 0,17 \\
\hline 25 & 0,16 & 0,13 \\
\hline 26 & 0,17 & 0,16 \\
\hline & & \\
\hline
\end{tabular}




\begin{tabular}{|l|l|l|}
\hline 27 & 0,16 & 0,18 \\
\hline 28 & 0,16 & 0,19 \\
\hline 29 & 0,16 & 0,17 \\
\hline 30 & 0,16 & 0,16 \\
\hline 31 & 0,16 & $?$ \\
\hline 32 & 0,15 & $?$ \\
\hline 33 & 0,14 & $?$ \\
\hline 34 & 0,1 & $?$ \\
\hline
\end{tabular}

12 